\title{
HUBUNGAN INDEKS MASSA TUBUH (IMT) DENGAN RASIO VOLUME EKSPIRASI PAKSA SATU DETIK PERTAMA PER KAPASITAS VITAL PAKSA (VEP1/KVP) PADA PASIEN ASMA STABIL DI RSUD KOTA MATARAM 2019
}

\author{
Prasetya Angga Firmansyah*, Risky Irawan**, Dian Rahadianti***, \\ Fachrudi Hanafi****
}

Fakultas Kedokteran Universitas Islam Al-Azhar

Jl. Unizar No. 20 Turida Mataram

Email: Prasetyaangga.pa@gmail.com

\begin{abstract}
ABSTRAK
Saat ini, asma masih menjadi salah satu masalah kesehatan utama di negara maju dan nonindustri. Gold standart dalam pemeriksaan penyakit asma adalah spirometri. Parameter yang dinilai dalam pemeriksaan spirometri untuk menilai derajat obstruksi pasien asma adalah VEP1/KVP. Perubahan pada IMT baik overweight maupun underweight akan menyebabkan perubahan mekanik dan kimiawi sistem pernapasan yang nantinya berperan sebagai faktor yang berpengaruh dan memperberat nilai VE1/KVP pada penderita asma. Alasan pemeriksaan ini adalah untuk mengetahui hubungannya antara indek massa tubuh dengan rasio volume ekspirasi paksa satu detik pertama per kapasital vital paksa pada pasien asma stabil di RSUD Kota Mataram 2019. Penelitian ini merupakan pemeriksaan logis observasional, dengan rencana cross sectional. Sumber informasi yang digunakan dalam penelitian ini adalah informasi opsional dari catatan klinis pasien asma rawat jalan di RSUD Kota Mataram 2019 berupa data berat badan, dan tinggi badan serta nilai VEP1/KVP. Sampel pada penelitian ini berjumlah 118 orang. Analisis data menggunakan rank spearman dengan bantuan software SPSS versi 25 . Konsekuensi dari pemeriksaan didapatkan $p$-value sebesar 0,000 ( $p$-value $\leq 0,05$ ) yang berarti terdapat hubungan antara BMI dan VEP1 / KVP pada pasien asma stabil di RSUD Kota Mataram 2019.
\end{abstract}

Kata Kunci: Asma stabil, Indeks Massa Tubuh, VEP1/KVP.

\section{ABSTRACT}

Right now, asthma is as yet one of the principle medical issues in both created and nonindustrial nations. The highest quality level in inspecting asthma is spirometry. The boundary evaluated in the spirometry assessment to survey the level of impediment in asthma patients was FEVI/FVC. Changes in BMI both overweight and underweight will 
cause mechanical and synthetic changes in the respiratory framework which will later go about as an impacting factor and bother the VE1/KVP esteem in asthma patients. The reason for this examination to decide the connection between weight file and the proportion of constrained expiratory volume of the first second per constrained fundamental limit in stable asthma patients at Mataram City Clinic 2019. This examination was an observational scientific contemplated, with a cross sectional plan. This examination utilizing optional information from clinical records of asthma patients as weight and tallness information just as VEP1/KVP esteems. The patients are going through outpatient at the Mataram City Medical clinic in 2019. The example in this investigation added up to 118 individuals. Information examination utilized position spearman with the assistance of SPSS form 25 programming The aftereffects of the investigation utilizing Rank Spearmen acquired a p-value of 0.000 ( $p$-value $\leq 0.05$ ), which implies that there is a connection among BMI and FEVI/FVC in stable asthma patients at Mataram City Clinic 2019.

Keywords: Asthma, body mass index, FEVI/FVC.

\section{PENDAHULUAN}

Saat ini asma adalah salah satu kondisi medis utama di negara-negara maju dan non-industri Sesuai informasi dari laporan Global Initiatif for Asthma (GINA) 2017, dinyatakan bahwa tingkat asma secara keseluruhan mencapai 1$18 \%$ dan dinilai bahwa 300 juta orang di dunia ini mengalami efek buruk. Asma yang didominasi asma di Indonesia sendiri pada tahun 2018 mencapai 2,4\% dengan provinsi Daerah Istimewa Yogyakarta (DIY) berada di peringkat pertama dengan angka kejadian mencapai 4,5\%, sementara provinsi Nusa Tenggara Barat (NTB) berada di peringkat ke 7 dengan angka kejadian mencapai 2,5\%. Data yang diperoleh peneliti dari poli paru Rumah Sakit Umum Daerah (RSUD) Kota Mataram total pasien asma yang menjalani rawat jalan selama tahun 2019 sebanyak 711 orang. Jumlah tersebut menunjukkan angka kejadian asma di RSUD kota Mataram masih cukup tinggi jika dibandingkan dengan kasus di RSUD provinsi NTB yang secara akumulatif relatif sama (GINA, 2017; Riskesdas, 2018).

Asma adalah penyakit heterogen dengan siklus penyebab berbeda yang mendasarinya. Pada asma terdapat suatu pembagian kelompok yang didasari oleh segmen demografis, klinis dan / atau atribut patofisiologis yang sering disebut sebagai 'fenotip asma'. Salah satu fenotipe klinis asma yang telah diidentifikasi dan disebutkan dalam Global Inititatif for Asthma yaitu asma 
dengan kegemukan. Beberapa pasien gemuk dengan asma memiliki indikasi pernafasan yang mencolok dan sedikit inflamasi eosinofilik pada saluran napas. Berdasarkan karakteristik tersebut, terlihat adanya suatu hubungan antara obesitas dengan asma. Hal ini juga diperkuat dengan hasil dari uji Liu Yong et al (2015) mengenai hubungan antara Indeks Massa Tubuh (IMT) dengan efek samping pernafasan, asma dan Chronic Obstructive Pulmonary Disease (COPD) yang menunjukkan bahwa orang yang berada pada batasan kelas IMT, khususnya underweight, overweight atau gemuk, wajib melaporkan asma dan / atau COPD dibandingkan orang dengan IMT biasa (Haitamy, 2017; Liu et al, 2015).

Gold standart dalam
pemeriksaan penyakit asma adalah
spirometri. Parameter yang dinilai dalam
pemeriksaan spirometri adalah. VEP1, KVP atau VEP1/KVP. Faktor-faktor yang berpengaruh terhadap nilai spirometri baik VEP1, KVP maupun VEP1/KVP diantaranya adalah usia, jenis kelamin, perokok aktif maupun pasif, genetik, dan IMT. Beberapa penelitian menunjukkan bahwa IMT memiliki hubungan terhadap nilai spirometri pada pasien asma. Rahmawati (2014) menunjukkan pasien asma dengan kelompok IMT obesitas memiliki hubungan terhadap nilai spirometri pada parameter VEP1 (Otrowski et al, 2006; Andayani, 2017; Rahmawati, 2014; Liu et al, 2015).

Seseorang dengan berat badan berlebih (gemuk-obesitas) dan underweight (kurus) memiliki resiko yang tinggi untuk terkenanya asma, yang berpengaruh terhadap penurunan nilai faal paru. Mekanisme yang menjelaskan diantaranya, seseorang dengan berat badan gemuk-obesitas menunjukkan adanya perubahan pada proses mekanik pernapasan dan respon inflamasi pada saluran pernapasan. Perubahan pada sistem mekanik pernapasan disebabkan karena adanya jaringan adiposa di sekitar tulang rusuk, yang mengisi dinding dada mengakibatkan tekanan dan penetrasi jaringan lemak papa otot dada, yang menyebabkan penurunan fungsi otot dan tulang pernapasan sehingga compliance dinding dada menurun. Hal ini akan meningkatkan kerja pernapasan akibat penurunan volume residu, kapasitas vital dan kapasitas total paru yang nantinya akan mempengaruhi nilai VEP1, KVP maupun VEP1/KVP. Teori lain tentang sitokin proinflamasi ialah jaringan adiposa mensekresi sitokin, leptin, Tumor Necrosis Factor- $\alpha$ (TNF- $\alpha$ ), Interleukin (IL)-6 yang memiliki efek proinflamasi pada saluran pernafasan yang dapat menyebabkan hiperresponsivitas pada saluran pernafasan dan menimbulkan obstruksi 
serta penurunan nilai VEP1 (Nair et al, 2009; Sutherland et al, 2008; Amanda, 2015; Haitamy, 2017).

Hubungan lain antara underweight dan obstruksi saluran pernapasan dapat dilihat dari efek negatif malnutrisi terhadap struktur pernapasan.

Kekurangan makanan yang sehat berdampak negatif pada bentuk, fleksibilitas dan kapasitas paru-paru, kekuatan dan halangan otot pernapasan, sistem perlindungan tubuh, dan regulasi napas yang nantinya meningkatkan gangguan pernapasan termasuk asma (Fasitasari, 2013; Fujianti et al, 2015).

Beberapa penelitian yang telah dilakukan belum ada yang melihat mengenai hubungan IMT dengan nilai rasio VEP1/KVP pada pasien asma. Akan tetapi, seperti yang telah disebutkan oleh GINA (2019) bahwa obesitas merupakan fenotipe dari penyakit asma dan penelitian Andayani et al (2017) dan Haitamy et al (2017) telah menunjukkan hubungan serius antara berat badan dan kejadian asma. Eksplorasi ini juga didukung oleh penelitian Nasiri et al (2016) dengan hasil

\section{METODE PENELITIAN}

Eksplorasi jenis ini merupakan penelitian observasional kuantitatif dengan rencana eksplorasi crosssectional. Penyelidikan diarahkan pada 29 September hingga 9 Oktober 2020. menunjukkan IMT berhubungan dengan tingkat keparahan asma. Penelitian lain yang dilakukan oleh Rahmawati (2014) menunjukkan terdapat perbedaan nilai VEP1 pasien asma pada kategori IMT normoweight dengan pasien asma pada kategori IMT overweight. Dengan adanya hubungan antara IMT dengan penyakit asma serta belum adanya penelitian yang menganalisa variabel IMT dengan perbandingan VEP1/KVP pada pasien asma, penulis tertarik untuk menyelidiki hubungan antara IMT dengan rasio VEP1/KVP pada pasien asma stabil di RSUD kota Mataram Tahun 2019.

Adapun tujuan dalam penelitian ini yaitu mengetahui hubungan antara IMT dengan rasio VEP1/KVP pada pasien asma stabil di RSUD Kota Mataram 2019. Serta manfaat yang dapat diambil dalam penelitian ini berupa meningkatkan pengetahuan pembaca, meningkatkan pengetahuan masyarakat tentang hubungan IMT dengan rasio VEP1/KVP pada pasien asma stabil, serta sebagai referensi penelitian dimasa yang akan datang.

Sumber informasi yang digunakan dalam pemeriksaan ini adalah informasi tambahan yang diperoleh dari catatan klinis RSUD Kota Mataram berupa berat badan, tinggi badan dan VEP1/KVP. 
Populasi keseluruhan pada penelitian ini adalah seluruh pasien asma stabil yang menjalani rawat jalan di poli pulmonology RSUD Kota Mataram periode Oktober sampai dengan Desember 2019 sebanyak 164 kasus. Sampel minimal yang harus didapatkan dalam penelitian ini sebesar 115 orang dengan cara purposive sampling. Kreteria inklusi dalam penelitian ini yaitu (1) Semua pasien asma stabil yang menjalani rawat jalan di poli pulmonology RSUD Kota Mataram periode Oktober sampai dengan Desember 2019. (2) Usia 18-60 tahun. Syarat pengeluaran sampel dalam penelitian ini ini adalah (1) Pasien dengan informasi rekam medis yang tersedia (Berat badan, tinggi badan, dan nilai VEP1/KVP) (2) Pasien asma stabil dengan penyakit metabolik (DM, hipertiroid). (3) Pasien memiliki penyakit paru lain selain asma (PPOK, TB paru, bronkiektasis, emfisema dan lain lain) (4) Pasien asma dengan penyakit immunocompromised (HIV, SLE) (5) Pasien asma dengan keganasan (kanker paru dan kanker luar paru). Pada penelitian ini, analisis data dilakukan menggunakan komputer melalui SPSS for Windows versi 25. Dalam penelitian ini, tes terukur yang digunakan adalah rank Spearman.

\section{HASIL PENELITIAN}

Penelitian ini ditujukan di RSUD Kota Mataram mulai tanggal 29 September 2020 sampai dengan 9 Oktober 2020 dengan metode pemeriksaan yang digunakan adalah strategi purposif sampel dengan ukuran sampel yang diperoleh dalam penelitian ini sebanyak 118 orang. Setelah dilakukan penelitian dan diperoleh data, selanjutnya data tersebut dianalisis secara univariat dan bivariat untuk kemudian dilihat karakteristik dari masing-masing sampel dan menilai hubungan antar variabel.

Tabel 1. Karakteristik Pasien Berdasarkan Usia

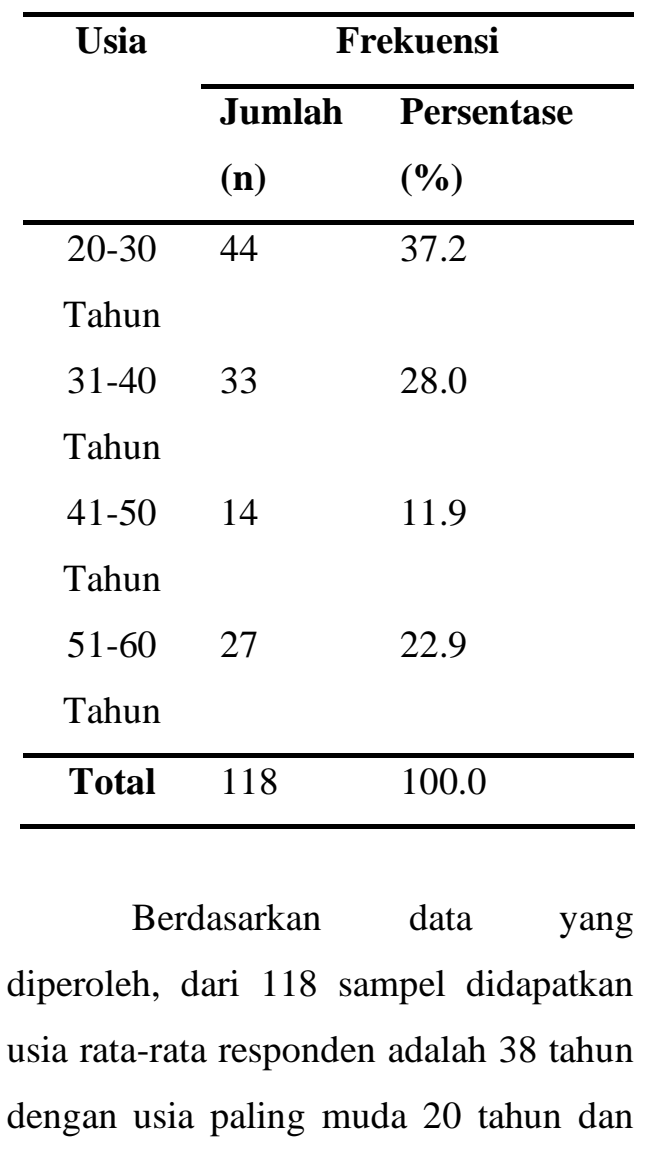


yang paling mapan 60 tahun. Kasus terbanyak ditemukan pada kelompok umur 20-30 tahun di atas 44 orang $(37,2 \%)$ dan paling sedikit terjadi pada kelompok umur 41-50 dengan 14 orang $(11,9 \%)$. Hasil tersebut dilihat pada tabel 1.

Tabel 2. Karakteristik Pasien Berdasarkan Jenis Kelamin.

\begin{tabular}{cll}
\hline Jenis & \multicolumn{2}{c}{ Frekuensi } \\
\cline { 2 - 3 } Kelamin & Jumlah & Persentase \\
& $(\mathbf{n})$ & $(\%)$ \\
\hline Laki-laki & 81 & 68.6 \\
Perempuan & 37 & 31.4 \\
\hline Total & 118 & 100.0 \\
\hline
\end{tabular}

Berdasarkan informasi yang diperoleh, dari 118 kasus, peningkatan jenis kelamin tertinggi adalah laki-laki sebanyak 81 orang $(68,6 \%)$ dan kasus asma dengan orientasi seksual perempuan di atas 37 orang $(31,4 \%)$. Hasil ini terlihat di tabel 2.

Tabel 3. Karakteristik Pasien Berdasarkan Berat Badan.

\begin{tabular}{cll}
\hline Berat & \multicolumn{2}{c}{ Frekuensi } \\
\cline { 2 - 3 } Badan & $\begin{array}{l}\text { Jumlah } \\
(\mathbf{n})\end{array}$ & $\begin{array}{l}\text { Persentase } \\
(\%)\end{array}$ \\
\hline$\leq 40 \mathrm{Kg}$ & 1 & 0.8 \\
$41-50 \mathrm{Kg}$ & 18 & 15.3 \\
$51-60 \mathrm{Kg}$ & 39 & 33.1 \\
$61-70 \mathrm{Kg}$ & 36 & 30.5 \\
\hline
\end{tabular}

\begin{tabular}{cll}
$71-79 \mathrm{Kg}$ & 23 & 19.5 \\
$\geq 80 \mathrm{Kg}$ & 1 & 0.8 \\
\hline Total & 118 & 100.0 \\
\hline
\end{tabular}

Berdasarkan informasi yang diperoleh, dari 118 orang, berat badan rata-rata responden adalah $62 \mathrm{~kg}$ dengan berat badan paling minimal $38 \mathrm{~kg}$ dan berat badan tertinggi adalah $80 \mathrm{~kg}$. Hasil penelitian ini menemukan bahwa sebagian besar pasien asma berada dalam kelompok dengan berat 51-60 kg lebih dari 39 orang $(33,1 \%)$. Hasil ini terlihat di Tabel 3.

Tabel 4. Karakteristik Pasien Berdasarkan Tinggi Badan.

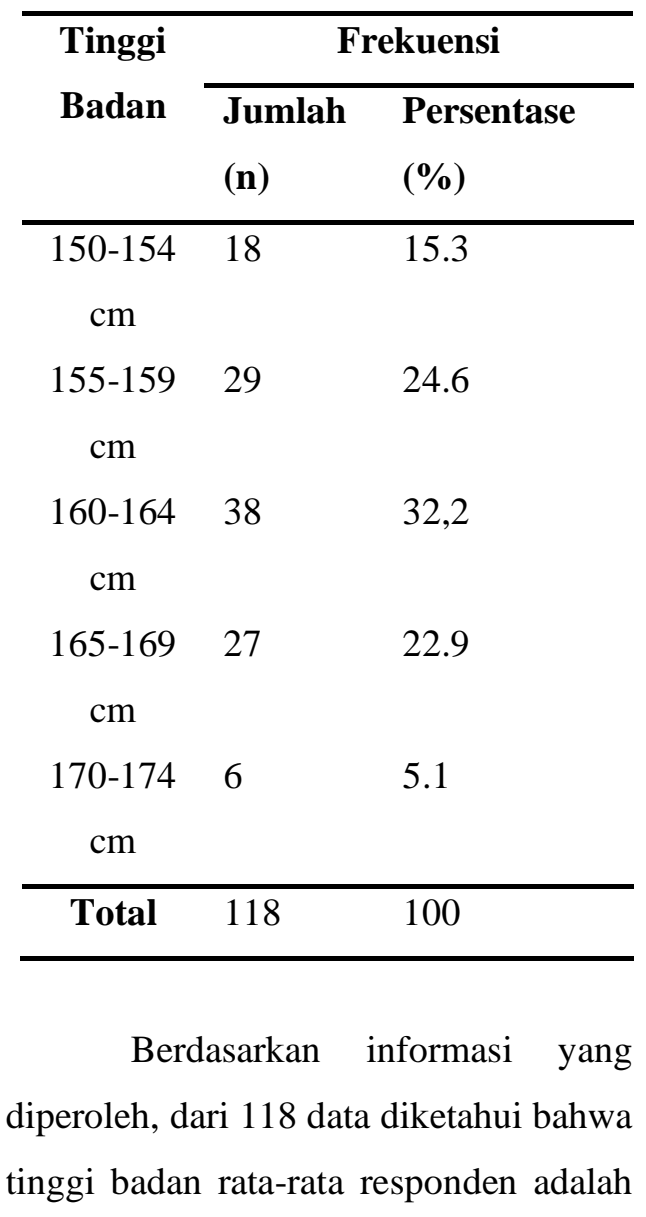


$159,5 \mathrm{~cm}$ dengan tinggi badan paling minimal $150 \mathrm{~cm}$ dan paling tinggi 174 $\mathrm{cm}$. Hasil pemeriksaan ini menemukan bahwa sebagian besar penderita asma berada pada kelompok tinggi $160-164 \mathrm{~cm}$ di 38 orang $(32,2 \%)$ dan untuk kasus paling sedikit ditemukan pada kelompok tinggi 170-174 cm di atas enam orang $(5,1 \%)$. ). Hasil ini terlihat di tabel 4 .

\section{Tabel 5. Karakteristik Pasien} Berdasarkan IMT.

\begin{tabular}{lll}
\hline Indeks & \multicolumn{2}{l}{ Frekuensi } \\
\cline { 2 - 3 } Massa & Jumlah & Presentase \\
Tubuh & $(\mathbf{n})$ & $(\%)$ \\
\hline $\begin{array}{c}\text { Undeweight } \\
\text { (kurus) }\end{array}$ & 13 & 11.0 \\
Normal & 50 & 42.4 \\
$\begin{array}{c}\text { Overweight } \\
\text { (gemuk- }\end{array}$ & 55 & 46.6 \\
obesitas) & & \\
\hline Total & 118 & 100.0 \\
\hline
\end{tabular}

Berdasarkan data yang diperoleh, dari 118 sampel didapatkan, sebagian besar penderita asma stabil di RSUD Kota Mataram masuk dalam kategori IMT yang overweight sebanyak 55 orang $(46.6 \%)$. Hasil tersebut dilihat pada Tabel 5.
Tabel 6. Karakteristik Pasien Derajat Obstruksi.

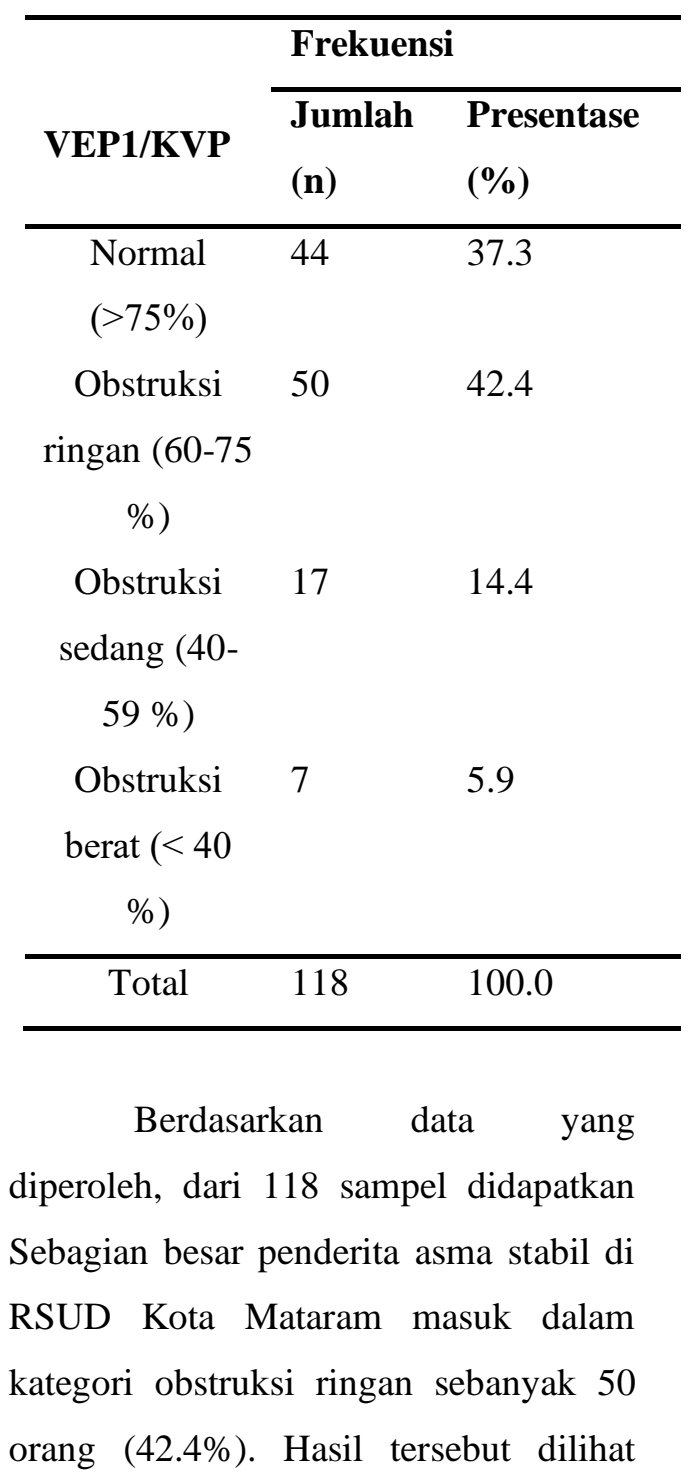
pada tabel Tabel 6. 
Tabel 7. Hubungan IMT dengan VEP1/KVP pasien asma.

\begin{tabular}{|c|c|c|c|c|c|c|c|c|c|c|}
\hline \multirow{3}{*}{ VEP1/KVP } & \multicolumn{6}{|c|}{ Indeks Massa Tubuh } & \multicolumn{4}{|c|}{$P$ - } \\
\hline & \multicolumn{2}{|c|}{$\begin{array}{c}\text { Underweig } \\
\text { ht }\end{array}$} & \multicolumn{2}{|c|}{ Normal } & \multicolumn{2}{|c|}{$\begin{array}{c}\text { Overweigh } \\
\mathbf{t}\end{array}$} & & llah & $\begin{array}{l}\text { Val } \\
\text { ue }\end{array}$ & $\mathbf{r}_{\mathrm{s}}$ \\
\hline & $\mathrm{N}$ & $\%$ & $\mathrm{~N}$ & $\%$ & $\mathrm{~N}$ & $\%$ & $\mathrm{n}$ & $\%$ & & \\
\hline Normal & 7 & 15.9 & 37 & 84.1 & 0 & 0.0 & 44 & 100.0 & & \\
\hline $\begin{array}{c}\text { Obstruksi } \\
\text { ringan }\end{array}$ & 5 & 10.0 & 11 & 22.0 & 34 & 68.0 & 50 & 100.0 & & \\
\hline $\begin{array}{c}\text { Obstruksi } \\
\text { sedang }\end{array}$ & 0 & 0.0 & 1 & 5.9 & 16 & 94.1 & 17 & 100.0 & 0.000 & 0.638 \\
\hline $\begin{array}{c}\text { Obstruksi } \\
\text { berat }\end{array}$ & 1 & 14.3 & 1 & 14.3 & 5 & 71.4 & 7 & 100.0 & & \\
\hline Total & 13 & 11.0 & 50 & 42.4 & 55 & 46.6 & 118 & 100.0 & & \\
\hline
\end{tabular}

Berdasarkan analisis yang dilakukan, dari 118 sampel didapatkan hasil responden yang memiliki nilai VEP1/KVP normal terbanyak jatuh pada kelompok IMT dengan kategori normal sebesar 37 orang $(84.1 \%)$. Responden yang memiliki nilai VEP1/KVP obstruksi ringan terbanyak jatuh pada responden yang memiliki IMT dengan kategori overweight sebesar 34 orang (68.0\%), dan paling sedikit jatuh pada IMT dengan kategori underweight sebanyak lima orang (10.0\%). Responden yang memiliki nilai VEP1/KVP obstruksi sedang terbanyak jatuh pada responden yang memiliki IMT dengan kategori overweight sebesar 16 orang $(94.1 \%)$. Dan responden yang Jurnal Kedokteran

Vol. 06 No. 02 Juni 2021 memiliki nilai VEP1/KVP obstruksi berat terbanyak jatuh pada responden yang memiliki IMT dengan kategori overweight sebesar lima orang (71.4\%), dan paling sedikit jatuh pada IMT dengan kategori normal dan underweight dengan masing masing satu orang (14.3\%).

Berdasarkan hasil analisis yang menggunakan rank Spearman didapatkan nilai $p$-value 0,000 ( $P$-value $\leq 0,05$ ) yang artinya Ho ditolak, hasil tersebut menunjukkan terdapat hubungan yang signifikan antara IMT dengan Rasio VEP1/KVP pada pasien asma stabil di RSUD kota Mataram. Nilai koefisien korelasi Rank Spearman yang didapatkan pada penelitian ini adalah sebesar 0.638 yang berarti kedua 
variabel memiliki kekuatan hubungan yang kuat. Dan berdasarkan arah hubungan, hasil analisis menunjukkan arah hubungan kedua variabel adalah positif.

\section{PEMBAHASAN}

Pada penelitian ini karakteristik usia responden dari 118 sampel, didapatkan kelompok tertinggi adalah umur 20-30 tahun yang mana usia tersebut termasuk dalam kelompok usia produkktif. Hasil ini sesuai dengan hasil Anriyanti et al (2013) dan Rahmawati et al (2014) menunjukan bahwa mayoritas usia responden yang mengalami serangan asma berada pada usia produktif. Menurut Maulana et al (2020) Tingkat asma pada usia produktif dikaitkan dengan paparan berturut-turut terhadap alergen, merokok, variasi hormonal, peradangan, dan penyakit pernapasan, dll.

Korban asma stabil dalam penelititan ini lebih dominan pada lakilaki (68.6\%) dibandingkan perempuan (31.4\%). Hasil ini tidak sama dengan pemeriksaan yang dipimpin oleh Haitamy et al (2015) dan Rahmawati et al (2014) melaporkan dari 75 sampel yang diteliti, sebanyak (62.3\%) adalah perempuan dan (37.7\%) adalah laki-laki. Eksplorasi yang dipimpin oleh Rahmawati et al (2014) juga memperoleh hasil yang serupa yaitu dari total 47 sampel yang diteliti, diperoleh 14 orang adalah laki-laki dan 33 orang adalah perempuan. Perbedaan antara hasil eksplorasi dengan penelitian masa lalu dapat terjadi karena jumlah pemeriksaan dalam penelitian ini lebih banyak daripada pemeriksaan sebelumnya yang memungkinkan sampel terambil acak, yang membuat orientasi seksual laki-laki menjadi dominan dalam pemeriksaan ini. Hal ini juga didukung oleh eksplorasi yang diarahkan oleh Raji et al (2019) di Iran dengan peserta 5708 individu, yang menunjukkan bahwa tidak ada perbedaan yang besar pada kasus asma yang bergantung pada orientasi seksual lakilaki $(50,7 \%)$ dan jenis kelamin perempuan $(49,3 \%)$.

Dari hasil analisis berdasarkan IMT, dari 118 sebagian besar penderita asma stabil di RSUD Kota Mataram masuk dalam kategori IMT yang overweight sebanyak 55 orang (46.6\%). Hasil ini sejalan dengan penelitian yang diarahkan oleh Rahmawati et al (2014) yang ditunjukkan pasien asma dengan overweight lebih banyak $(51,1 \%)$ daripada pasien asma dengan kategori normoweight $(48,9 \%)$. Hasil tersebut juga didukung dengan penelitian Andriani et al (2019) yang memperoleh hasil Pasien asma dengan IMT kelebihan berat badan lebih banyak (49,2\%), dibandingkan dengan asma dengan IMT biasa (44,4\%) maupun asma dengan 
underweight sebesar (6,3\%). Banyaknya kasus asma dengan overweight ini dikarenakan, kondisi overweight akan menyebabkan perubahan mekanik dan kimiawi sistem pernapasan, yang menjadi mekanisme dasar dalam terjadinya asma (Rahmawati, 2014; Andriani, 2019).

Hasil analisis berdasarkan nilai VEP1/KVP dari 118 pasien asma di RSUD Kota Mataram didapatkan Sebagian besar penderita asma stabil di RSUD Kota Mataram masuk dalam kategori obstruksi ringan sebanyak 50 orang (42.4\%). Derajat obstruksi ringan dapat terjadi karena beberapa hal seperti keberhasilan terapi dan terkontrolnya dari penyakit asma itu sendiri (GINA, 2019).

Dalam analisis rank Spearman, terdapat hubungan yang sangat besar antara IMT dengan proporsi VEP1 / KVP pada pasien asma stabil di RSUD Kota Mataram 2019. Koefisiensi korelasi Spearman $\left(\mathbf{r}_{\mathbf{s}}\right)$ pada penelitian ini sebesar 0,638 , artinya kedua variabel memiliki kekuatan korelasi yang kuat. Hal ini menunjukkan bahwa faktor IMT dapat mempengaruhi sekitar $63.8 \%$ nilai VEP1/KVP pada pasien asma. Hasil penelitian ini sesuai dengan eksplorasi Kasteleyn et al (2017) yang menunjukkan bahwa pasien asma dengan berat badan berlebih memiliki nilai VEP1/KVP yang lebih rendah dibandingkan dengan pasien asma tanpa obesitas. Berdasarkan arah hubungan, hasil analisis menunjukkan arah hubungan positif pada kedua variabel, yang berarti bahwa kenaikan satu variabel berasosiasi dengan kenaikan variabel lain (berbanding lurus). Hal tersebut menunjukkan bahwa semakin tinggi IMT pada pasien asma maka semakin besar derajat obstruksi pasien tersebut (semakin memperkecil nilai VEP1/KVP).

Hasil dalam penelitian ini juga didapatkan bahwa jumlah pasien asma yang mengalami obstruksi sedang disertai IMT yang overweight lebih banyak 17 orang (94.1\%) jika dibandingkan dengan pasien asma yang mengalami obstruksi berat disertai IMT overweight 7 orang (71.4\%). Hal tersebut dapat dikarenakan beberapa faktor seperti teori yang disebutkan oleh GINA (2019) bahwa, penyakit asma merupakan penyakit obstruksi saluran napas yang sifatnya reversible. Hal ini menyebabkan pasien asma pasien asma yang mengalami obstruksi berat masih memungkinkan untuk kembali ke obstruksi sedang, obstruksi ringan maupun kembali ke keadaan normal jika mendapatkan pengobatan yang tepat. Faktor lain yang menyebabkan hal tersebut adalah dalam penelitian ini, peneliti tidak dapat memastikan apakah nilai VEP1/KVP yang diambil pada 
rekam medik dilakukan pada awal perawatan atau setelah perawatan. Hal tersebut di dukung dengan hasil penelitian Ananda (2020) yang menyatakan terdapat perbedaan nilai faal paru pasien asma pada awal perawatan dan setelah perawatan.

Sesuai dengan teori sebelumnya bahwa IMT adalah salah satu faktor resiko yang menyebabkan atau memperberat gejala dari penyakit asma. Mekanisme yang mendasari korelasi antara IMT dengan rasio VEP1 per KVP pada penderita asma stabil ini adalah jumlah lemak tubuh yang berlebih dapat menjadi penyebab dari perubahan mekanik dan kimiawi pada sistem pernapasan (Baffi et al, 2015). Perubahan mekanik yang terjadi berupa peningkatan jaringan adiposa di dinding dada dan dinding perut. Peningkatan jaringan adiposa ini menyebabkan penekanan di dinding dada sehingga mempengaruhi kerja otot dan tulang pernapasan dan menyebabkan penurunan daya complians paru, sehingga mengakibatkan penurunan functional residual capacity (FRC). Menurut Sherwood (2014) FRC adalah volume cadangan ekspirasi dan volume residu paru yang mana terganggunya volume tersebut akan mempengaruhi dan memperberat nilai VEP1/KVP pada pasien asma. Jaringan adipose yang berlebih di dinding perut juga akan mempengaruhi tekanan intra abdomen yang menyebabkan otot diafragma lebih terangkat dibanding normal yang nantinya mengakibatkan penurunan volume intra thorax dan berpengaruh terhadap kerja saluran napas perifer sehingga menimbulkan keluhan subjektif berupa dispnea dan akan memperberat keluhan sesak tersebut pada penderita asma. (Sudoyo, 2014; Berawi et al, 2017).

Perubahan kedua yang terjadi pada overweight adalah perubahan kimiawi. Jaringan adiposa pada obesitas dipercaya memproduksi sejumlah molekul pro-inflamasi seperti IL-6, eotaxin, TNF- $\alpha$, transforming growth factor (TGF)- $\beta 1$, leptin serta beberapa mediator lipid. Produksi molekul proinflamasi tersebut meningkat pada obesitas sehingga menimbulkan respons inflamasi sistemik. Tubuh manusia sendiri memiliki mekanisme pertahanan terhadap inflamasi sistemik dalam bentuk molekul adiponektin yang bersifat sebagai anti-inflamasi (Shore, 2008). Akan tetapi, keadaan obesitas menyebabkan adiponektin mengalami penurunan sehingga efek inflamasi akan semakin meningkat. Shore (2008) menyebutkan salah satu tempat mekanisme adiponektin bekerja adalah otot polos saluran napas. Beberapa penelitian bahkan telah menyampaikan bahwa penurunan adiponektin serum 
dapat menyebabkan peningkatan dalam jumlah besar masa otot polos melalui remodeling pada asma. Mediator lain yang meningkan adalah leptin. Penyebab obstruksi jalan napas pada asma yaitu hiperesponsif saluran napas dipercaya sebagai akibat dari peningkatan leptin. Obstruksi jalan napas sendiri akan menyebabkan hambatan udara saat ekspirasi, pemanjangan periode ekspirasi serta penurunan nilai VEP1 dan KVP (Nair et al 2008; Sutherland et al 2008; Sabirini, 2011).

\section{KESIMPULAN}

Berdasarkan hasil pemeriksaan, hubungan antara IMT dan rasio VEP1/KVP pada pasien asma stabil di RSUD Kota Mataram 2019 dapat cenderung disimpulkan bahwa ada hubungan kuat antara IMT dengan rasio VEP1/KVP pada pasien asma stabil di RSUD Kota Mataram ditandai dengan pvalue 0,000 (p-value $<0,050$ ) dan senilai koefisien korelasi 0,638 menandakan korelasi hubungan kedua variabel adalah kuat. Serta hasil analisis menunjukkan arah hubungan kedua variabel adalah positif.

\section{SARAN}

Disarankan untuk peneliti selanjutnya yang tertarik melanjutkan penelitian ini agar dapat mengkaji faktor lain yang dapat menjadi faktor perancu dalam penelitian sebagai contoh, data yang diambil harus sejenis apakah diawal perawatan atau diakhir perawatan, intensitas paparan allergen, lama pengobatan dan lain sebagainya.

\section{DAFTAR PUSTAKA}

Andayani, N. 2017. Hubungan Obesitas Terhadap Asma. Jurnal Kedokteran Syiah Kuala, 17(1), 54-59.

Andriani, F. P., Sabri, Y. S., \& Anggrainy, F. 2019. Gambaran Karakteristik Tingkat Kontrol Penderita Asma Berdasarkan Indeks Massa Tubuh (IMT) di Poli Paru RSUP. Dr. M. Djamil Padang pada Tahun 2016. Jurnal Kesehatan Andalas, 8(1), 89-95.

Anriyanti, D., Jemadi, R. 2013. Karakteristik penderita asma bronkial rawat inap di rumah sakit umum daerah Langsa tahun 20092012. Skripsi Universitas Sumatra Utara.

Ananda, D., \& Samosir, N. R. (2020). Incentive Spirometry dan Chest Therapy Efektif Dalam Mengurangi Kekambuhan Pada Kondisi Asma Bronkial. Jurnal Ilmiah Fisioterapi, 3(2), 38-46.

Baffi, C. W., Winnica, D. E., \& Holguin, F. 2015. Asthma and obesity: mechanisms and clinical implications. Asthma research and practice, l(1), 1.

Berawi, K. N., \& Ningrum, A. F. 2017. Faktor Risiko Obesitas dan Kejadian Asma. Jurnal Majority, 6(2), 6-11.

Fasitasari, M. 2013. Terapi Gizi pada Lanjut Usia dengan Penyakit Paru Obstruktif Kronik (PPOK) Januari - Juni 2013. Sains Medika. 5(1), 50-61.

Fujianti, P., Hasyim, H., \& Sunarsih, E. 2015. Faktor-Faktor yang Mempengaruhi Timbulnya Keluhan Gangguan Pernapasan pada Pekerja Mebel Jati Berkah Kota Jambi. Jurnal Ilmu Kesehatan Masyarakat, 6(3). 
GINA (Global Initiative for Astma). 2019. Pocket Guide For Asthma Management and Prevention.

Haitamy, N., \& Kadarullah, O. 2017. Pengaruh Obesitas Terhadap Terjadinya Penyakit Asma Di RS Islam Fatimah Cilacap. Sainteks, 12(2).

Kasteleyn, M. J., Bonten, T. N., de Mutsert, R., Thijs, W., Hiemstra, P. S., le Cessie, S., Taube, C. 2017. Pulmonary function, exhaled nitric oxide and symptoms in asthma patients with obesity: a crosssectional study. Respiratory research, 18(1), 205.

Kementerian RI tahun 2018. http://www.depkes.go.id/resources /download/infoterkini/materi_rako rpop_2018/Hasil\%20Riskesdas\%2 02018.pdf - Diakses 26 Februari 2020.

Liu, Y., Pleasants, R. A., Croft, J. B., Lugogo, N., Ohar, J., Heidari, K., \& Kraft, M. 2015. Body mass index, respiratory conditions, asthma, and chronic obstructive pulmonary disease. Respiratory medicine, 109(7), 851-859.

Maulana, Arief \& Prihartono, Nurhayati \& Yovsyah, Yovsyah. 2020. Hubungan Obesitas dengan Risiko Kejadian Penyakit Asma pada Perempuan Usia Produktif di Indonesia. Jurnal Epidemiologi Kesehatan Indonesia. 4(10).

Nair, P., Pizzichini, M. M., Kjarsgaard, M., Inman, M. D., Efthimiadis, A., Pizzichini, E., \& O'Byrne, P. M. 2009. Mepolizumab for prednisone-dependent asthma with sputum eosinophilia. New England Journal of Medicine, 360(10), 985993.

Nasiri, K, R., Hamedi, R., Nasirian, R., Farsani, M., Kashefi, H., Khalafi, B., \& Kooti, W. 2016. Association of body mass index with asthma severity and pulmonary function among asthmatic children. International Journal of Pediatrics, 4(9), 3551-3559.
Ostrowski, S., \& Barud, W. 2006. Factors Influencing Lung Function: Are The Predicted. Journal of physiology and pharmacology, 57.

Rahmawati, Galih Lidya, and Muhammad Fachri. 2014. Comparison of Various Degree of Stable Asthmatic Patients With Obesity and Normoweight at Jakarta Islamic Hospital Sukapura. JOURNAL OF THE INDONESIAN MEDICAL ASSOCIATION Majalah Kedokteran Indonesia 64(2).

Raji, H., Idani, E., Madadizadeh, F., Cheraghian, B., Shoshtari, M. H., \& Dastoorpoor, M. 2019. Prevalence of asthma and other allergic conditions in adults in Khuzestan, southwest Iran, 2018. BMC public health, 19(1), 303.

Riset Kesehatan Dasar (Riskesdas) 2018. Badan Penelitian dan Pengembangan Kesehatan.

Sutherland. T. J., Cowan, J. O., Young, S., Goulding, A., Grant, A. M., Williamson, A., \& Taylor, D. R. 2008. The association between obesity and asthma: interactions between systemic and airway inflammation. American journal of respiratory and critical care medicine, 178(5), 469-475.

Sherwood, L. 2014. Fisiologi manusia: dari sel ke sistem. Edisi 8. Jakarta: EGC.

Sabirina. N. A. 2011. Perbedaan Fungsi Paru antara Penderita Asma Obesitas dan Normoweight rentan Usia 30-40 tahun di Poli Asma RSUP Persahabatan periode Agustus 2008-Agustus 2010. Skripsi Fakultas Kedokteran UPN Veteran Jakarta, 1-47.

Shore, S, A. 2008. Obesity and asthma: Possible mechanisms. J Allergy Clin Immunol. 121(5):1087-93.

Sudoyo, A, W., Alwi, S, S., \& Simadribata, K, M. 2014. Buku Ajar Ilmu Penyakit Dalam Jilid 2 Edisi VI. Departemen Ilmu Penyakit dalam FKUI. Jakarta. 